\title{
Falta alguém em \\ Nuremberg: uma \\ representação \\ liberal de Vargas e \\ do Estado Novo no \\ pós-451
}

\section{Julia Nogueira Zon*}

DOI: 10.11606/issn.2318-8855.v10i1p194-217

Resumo: Este artigo objetiva analisar o modo como foi representado o Estado Novo e Getúlio Vargas pelos setores liberais no período que compreende a segunda metade da década de 1940 no Brasil, tomando por fonte o livro Falta Alguém em Nuremberg (1947), do jornalista David Nasser. Considerando que as representações políticas dificilmente constituem discursos imparciais, a análise busca atentar para os interesses que guiaram essas representações dentro de um contexto histórico marcado pelo processo de redemocratização, organização dos partidos políticos e emergência da classe trabalhadora no cenário político nacional. Partimos da proposta de apresentar de forma sucinta o debate historiográfico acerca do Estado Novo que serviu de guia para a realização do artigo. Dentro dessa perspectiva, investigamos como a representação negativa de Vargas dialogava com os novos interesses que se manifestavam pelos sujeitos e grupos políticos emergentes, uma vez que, com a democratização, a disputa partidária não podia ignorar o peso e a influência política que Vargas ainda exercia.

Palavras-chave: Estado Novo, Liberais, Nasser, Representações, Vargas.

\footnotetext{
${ }^{1}$ Este artigo foi resultado da pesquisa de Iniciação Científica intitulada Estado Novo: uma análise das representações do regime e de Getúlio Vargas, financiada pelo Programa Institucional de Bolsas de Iniciação Científica (PIBIC) do Conselho Nacional de Desenvolvimento Científico e Tecnológico (CNPq), sob orientação do Prof. Dr. Marcos Francisco Napolitano de Eugênio, professor de História do Brasil Independente II da Faculdade de Filosofia, Letras e Ciências Humanas da Universidade de São Paulo.

* Graduanda em História na Faculdade de Filosofia, Letras e Ciências Humanas da Universidade de São Paulo. Contato: julianogueirazon@gmail.com.
} 


\section{artigos}

\section{Falta alguém em Nuremberg}

Estado Novo, revisão da literatura e novas perspectivas

O Estado Novo (1937-1945) ganhou ênfase nas pesquisas acadêmicas a partir do movimento de compreensão do golpe de 1964, que colocou a necessidade do estudo do autoritarismo brasileiro em suas origens (CAPELATO, 2009, p. 26-27). A historiografia clássica que se debruçou sobre o regime estadonovista se baseou em modelos interpretativos fundamentados no conceito de populismo e no seu pressuposto principal, a saber: a manipulação das massas. Esses estudos começaram a ser questionados a partir da década de 1980 com a divulgação de trabalhos que passaram a revisar o governo Vargas a partir de outros prismas. Nesse sentido, o presente artigo é original em sua proposta na medida em que visa abarcar a Era Vargas na perspectiva de suas representações políticas no pós-45, apresentando, a partir da análise da obra Falta Alguém em Nuremberg (1947) de autoria do jornalista David Nasser, o momento de gênese de uma memória negativa acerca do varguismo, construída pela oposição liberal - agrupada na União Democrática Nacional (UDN) - pouco tempo depois da queda da ditadura.

Com o fim do regime militar de 64, as eleições diretas e a reorganização dos sindicatos e grupos políticos reacenderam o debate dos estudiosos em torno da abordagem política. Por conseguinte, a discussão sobre o populismo foi retomada nas discussões acadêmicas. É importante ressaltar que o conceito guarda relação direta com os estudos sobre o varguismo, uma vez que foi amplamente utilizado para elucidar o apoio da classe trabalhadora a Vargas e outros políticos trabalhistas entre os anos 1945 e 1964. Essas explicações normalmente traziam a ideia de que os regimes populistas conseguiram manipular e subordinar as massas através do desenvolvimento de uma eficiente máquina propagandística e do uso da ação policial como forma de coerção.

Segundo Carlo Romani, a historiografia da década de 1950-80 procurou explicar a modernização da sociedade brasileira como uma herança política do governo Vargas. Epígrafe, São Paulo, v. 10, n. 1, pp.194-217, 2021 


\section{artigos}

Julia Nogueira Zon

A base da interpretação estaria em mostrar como o populismo impossibilitou os trabaIhadores de se firmarem como sujeitos ativos na sociedade, fato que elucidaria a incapacidade de defesa do povo contra o golpe de 64 (ROMANI, 2015, p. 221). Predominante na historiografia brasileira até então, essa abordagem passou a ser objeto de revisão a partir da década de 1980, quando surgiram pesquisas que repensaram a relação entre camadas populares e Estado/líder no varguismo.

Um dos estudos mais exemplares dessa nova abordagem foi realizado por Ângela de Castro Gomes em sua obra A invenção do trabalhismo (1994). Neste trabalho, a autora teve como objetivo principal estudar o processo histórico envolvido na constituição da classe trabalhadora em ator político no Brasil, tendo como base a relação entre trabalhadores e Estado no período do Estado Novo.

Gomes recusa o uso do conceito de populismo, uma vez que ele pressupõe um processo de manipulação no qual o povo, destituído de consciência de classe, aparecia como objeto passivo diante da ação do Estado e não como ator político dotado de capacidade de escolha e participação (GOMES, 2001, p. 46). Desse modo, em substituição a chave explicativa do populismo, a autora propõe a utilização da expressão "pacto trabalhista":

A ideia de pacto procurava enfatizar a relação entre atores desiguais, mas onde não há um Estado todo-poderoso nem uma classe passiva porque fraca numérica politicamente. A lógica deste pacto, cuja efetivação estava sendo datada, precisava ser entendida numa perspectiva temporal muito mais ampla, que conectava o período do pré e do pós-30 e as experiências aí vivenciadas pela classe trabalhadora e pelo Estado. Neste aspecto particular, o trabalho procurava se contrapor a uma forte interpretação que explicava o sucesso populista como o resultado de um cálculo utilitário em que ganhos materiais eram trocados por obediência política, claramente referida à dimensão da manipulação. (GOMES, 2001, p. 47-48) 


\section{artigos}

\section{Falta alguém em Nuremberg}

Assim, segundo Gomes, durante o regime estadonovista, a relação entre governante e governados se deu através da "ideologia da outorga". Essa relação era mediada pela legislação social e baseava-se no pressuposto de doação. Os benefícios sociais eram apresentados à classe trabalhadora como um presente outorgado pela figura "generosa" do governante. Todavia, a legislação trabalhista não era uma caridade, pois pressupunha, dentro da relação de doação, o dever de dar e a obrigação de receber e retribuir, isto é, era dever do governante conceder ao povo a legislação trabalhista, assim como era obrigação do povo recebê-la - uma vez que lhe era um direito -, mas também retribuí-la. Por sua vez, essa retribuição viria sob a forma de obediência: não retribuir significava quebrar com a lógica da doação (GOMES, 1994, p. 210-212). Para tanto, ao trazer a ideia de pacto trabalhista, Gomes chamou atenção para a lógica simbólica, e não somente material, que guiava a relação entre classe trabalhadora e Estado.

O trabalho de Gomes foi significativo pois trouxe novas perspectivas de análise sobre temas que abrangem a classe trabalhadora, os sindicatos, o corporativismo e os movimentos sociais. A noção de "pacto trabalhista" e "ideologia da outorga" foram algumas das contribuições da autora ao debate historiográfico que abriram caminho para uma nova forma de se pensar a relação povo-Vargas, o papel desempenhado pelo Estado e o protagonismo dos trabalhadores. À vista disso, surgem pesquisas que problematizam a ideia da passividade das classes populares após e durante o Estado Novo, como, por exemplo, a obra Trabalhadores do Brasil: o imaginário popular (1997) do historiador Jorge Ferreira, cujo foco é direcionado para as camadas subalternas que tiveram seu protagonismo retirado e ocultado pela historiografia clássica centrada nos anos 1930-45.

Apesar de não negar a importância desempenhada pela propaganda política e pela repressão no regime varguista, Ferreira confronta e critica os estudos tradicionais 


\section{artigos}

Julia Nogueira Zon

que tomaram apenas o papel dessas duas variáveis para explicar o apoio dos trabalhadores a Vargas. Para o autor, "não há propaganda que transforme um personagem em líder político, em figura legendária, sem realizações que afetem a vida material e simbólica dos homens e mulheres que o reverenciam" (FERREIRA, 1997, p. 16), isto é, apesar da propaganda estatal ter sido utilizada de forma intensiva, Ferreira defende que não se pode minimizar o impacto que as leis sociais tiveram entre os trabalhadores e para a manutenção de Vargas no poder.

Procurando evidenciar como se processou a relação entre povo e presidente, o autor mostra que "o apoio que os populares manifestaram a Vargas não correspondia ao apoio que Vargas esperava deles" (FERREIRA, 1997, p. 54). Uma vez que dentro da lógica simbólica, as classes populares receberam, ressignificaram e se apropriaram do discurso estadonovista em benefício próprio, criando estratégias e realizando escolhas.

Em outro texto, intitulado A democratização de 1945 e o movimento queremista (2003), Ferreira estende sua análise para o processo de redemocratização brasileira. Seguindo a tese formulada em trabalho anterior, o autor rejeita a abordagem que analisa o movimento queremista ao longo do ano de 1945 como decorrência de uma política populista. De acordo com Ferreira, os trabalhadores viam na figura de Vargas o único capaz de preservar a legislação social, logo, ao participarem do movimento queremista e exigirem a Constituinte com Getúlio, as camadas populares estariam fazendo uma escolha que visava à manutenção dos seus direitos. Em outras palavras, a adesão dos trabalhadores ao queremismo teria sido fruto não da manipulação, mas sim de uma escolha. Nesse sentido, o autor defende que em virtude do movimento queremista os trabalhadores surgem no cenário político com consciência de seus interesses e vontade política. Assim, Jorge Ferreira empreende um estudo que atribui protagonismo às classes populares durante e pós-Estado Novo. 


\section{artigos}

\section{Falta alguém em Nuremberg}

Como já foi mencionado, a repressão e a propaganda política foram as principais chaves explicativas utilizadas pela historiografia tradicional para interpretar o sucesso do regime estadonovista e a adesão das massas ao projeto autoritário. Entretanto, é importante ressaltar que as pesquisas referentes à violência política empreendida pelo Estado varguista só foram iniciadas de forma incisiva a partir do processo de redemocratização brasileira na década de 1980. Como lembra Carlo Romani, um fator relevante para o surgimento desses trabalhos foi a abertura dos arquivos da Delegacia Especializada de Ordem Política e Social de São Paulo (DEOPS) na década de 1990, que permitiu aos pesquisadores analisarem o modo de funcionamento do aparato repressivo no país (ROMANI, 2015, p. 213-214).

Em diálogo com o debate que põe em evidência o autoritarismo do Estado Novo, Maria Helena Capelato em Multidões em cena (2009), promove um estudo comparado da propaganda política no varguismo e no peronismo com a proposta de compreender a natureza dos dois regimes. Capelato adentra o terreno do simbólico e do imaginário popular para mostrar como a propaganda, ao interferir no campo da cultura, política e educação, pretendia manipular os sentimentos da sociedade. Todavia, é importante frisar que a autora não superestima o papel da propaganda como instrumento de manipulação e alienação das massas nos regimes ditos populistas. Pelo contrário, Capelato discorre que a propaganda política foi um dentre vários instrumentos utilizados e adaptados pelos regimes autoritários conforme suas próprias realidades. À vista disso, a autora não trabalha com o conceito de populismo, uma vez que entende que "os modelos e as tipologias construídos para explicar o populismo na América Latina não levaram devidamente em conta as particularidades nacionais nem as especificidades conjunturais" (CAPELATO, 2009, p. 23). 


\section{artigos}

Julia Nogueira Zon

Mesmo evidenciando que o varguismo e o peronismo sofreram fortes influências do nazifascismo europeu - sobretudo no que se refere à montagem do sistema propagandístico -, Capelato deixa claro que esses regimes não podem ser tomados como fenômenos essencialmente fascistas. Ao adentrar nessa discussão, a autora se contrapõe a uma corrente de autores que durante os anos 1980 interpretaram os governos de Vargas e Perón à luz do totalitarismo. Utilizando como base o trabalho de Roberto Romano, Capelato defende que não existiram regimes totalitários na América Latina e que "[...] até os casos mais conspícuos de regimes autoritários dos anos 30-40, o argentino e o brasileiro, não se mostram adequados ao conceito", dado que "apenas em níveis ideais, propagandísticos ou em tentativas isoladas, pode-se falar em totalitarismo" (CAPELATO, 2009, p. 35).

Por outro lado, dentre as pesquisas que privilegiaram o tema da repressão e violência no Estado varguista está a obra O mundo da violência: a polícia na Era Vargas (1994) de Elizabeth Cancelli, que realizou um estudo sobre o aparato policial do Estado Novo. A autora parte da ideia de que o regime inaugurado a partir de 1930 fundamentou-se na "busca de uma identidade nacional", "na manipulação dos sentimentos" e na "brutalidade do totalitarismo" para impulsionar as massas (CANCELLI, 1994, p. 5). Cancelli destaca que o Estado foi marcado por duas facetas: a normativa e a prerrogativa, a primeira se processaria conforme as normas legais, enquanto a segunda seria representada pelos círculos policiais numa esfera à margem da lei. Dessa forma, sua argumentação procura demonstrar que o Estado varguista foi um regime totalitário que utilizou a repressão e a violência como formas de legitimar e exercer o poder. Segundo Cancelli, a polícia foi um dos principais sustentáculos do regime e de seu líder, uma vez que, ao instaurar o terror, a instabilidade e a perseguição sistemática aos opositores políticos, permitiu a consolidação do projeto totalitário: 


\section{artigos}

\section{Falta alguém em Nuremberg}

A polícia não era nada menos do que o elemento que fundamentava o poder de Vargas, porque mantinha o terror nas ruas, fazia com que a sociedade como um todo se sentisse impotente. Escolhia os novos inimigos a serem perseguidos e seguia, às cegas, às diretrizes impostas por Getúlio Vargas quanto aos caminhos a serem seguidos pela nação. (CANCELLI, 1994, p. 215)

Ao analisar o funcionamento do aparato policial estadonovista e expor a arbitrariedade e a violência que guiaram as ações do Estado no período, a pesquisa de Cancelli confronta a própria imagem positiva que o regime procurou construir para si. Assim, a autora chama atenção para uma face do Estado Novo pouco conhecida e explorada pela historiografia até então. Entretanto, seu trabalho foi criticado por Jorge Ferreira que, como referido anteriormente, discorda da interpretação historiográfica tradicional focada na repressão e na propaganda política para justificar o apoio das classes populares ao regime e a Vargas. Nesse sentido, contrapondo-se à Cancelli, Ferreira parte de uma abordagem histórica a fim de reconstituir a vida cotidiana dos presos políticos de forma a expor suas estratégias de sobrevivência dentro dos sistemas penitenciário e carcerário. A partir desse estudo, Ferreira mostra que é possível perceber uma série de contradições internas no aparato repressivo do Estado que sugerem que "mesmo em sua dimensão mais tenebrosa, o regime político não foi coeso, unificado e muito menos 'total'"' (FERREIRA, 1997, p. 92-93), como afirma Cancelli na sua análise.

Ainda de acordo com Jorge Ferreira, a arbitrariedade e a violência praticadas pelo regime ficaram reservadas quase que exclusivamente à ação da polícia sob chefia de Filinto Müller, não havendo qualquer menção, por parte do autor, a Vargas ou ao fato da polícia estar sob supervisão do Presidente da República. Indiretamente, a culpa é atribuída a Müller e não ao chefe do Estado Novo:

Nesse âmbito, o poder, particularmente do Ministério da Justiça e do Judiciário, não exercia qualquer controle. Até mesmo em assuntos que estavam sob a responsabilidade exclusiva dos médicos e burocratas do Ministério da Justiça, Fi- 


\section{artigos}

Julia Nogueira Zon

linto Müller, de maneira autoritária e arbitrária, interferia sem maiores explicações. [...] Assim, decisões arbitrárias, prisões sem mandado judicial, torturas e assassinatos eram praticados pelo grupo de Filinto Müller sem maiores controles ou cerceamentos. (FERREIRA, 1997, p. 120-121)

Por outro lado, Cancelli deixa explícito que Filinto Müller respondia diretamente às ordens dadas por Vargas. Ao analisar a documentação do período, a autora assinala, por exemplo, que em determinado episódio Müller escreveu ao chefe do Estado Novo “[...] a respeito da detenção de presos políticos sem processo formal que 'somente ao presidente da República devo dar conta de meus atos no exercício do cargo com que sua confiança me honrou"' (CANCELLI, 1994, p. 51). Dessa forma, Cancelli ressalta como a figura de Vargas foi poupada de quaisquer responsabilidades sobre os crimes cometidos durante o seu primeiro governo:

A ação policial caminhava como se fosse um poder independente, paralelo e despersonificado. A repressão e o sofrimento não eram atribuídos ao presidente ou ao chefe de polícia. Brotavam como fruto de uma ação impessoal, como algo que acontecesse por si, à revelia de qualquer fato ou vontade. (CANCELLI, 1994, p. 194)

O modo como Vargas e o Estado Novo foram representados pela historiografia brasileira também foi alvo de debate no meio acadêmico. Em um ensaio intitulado $A$ ditadura tolerada (2015) Carlo Romani faz um balanço das revisões historiográficas que tratam da Era Vargas. O principal ponto do autor é criticar a persistência de uma memória positiva do varguismo, sobretudo quando associado ao trabalhismo, nas pesquisas acadêmicas, mesmo tendo em vista os crimes políticos cometidos pelo regime e o legado policial repressivo deixado:

A herança das formas de tutela política autoritária, policial, corporativista, populista, trabalhista, mística, qualquer termo que se queira usar, herança que ainda persiste, é tão danosa à construção da mais ampla democracia quanto a do antigo clientelismo e mandonismo dos potentados regionais pré-30 contra 


\section{artigos}

\section{Falta alguém em Nuremberg}

os quais se insurgiram os modernizadores da nação. Uma herança que se projetou firmemente durante os anos seguintes ao suicídio de Vargas, manteve-se nos porões da ditadura de 64, assentada no legado pernicioso da polícia política, e seguiu, após seu término, deixando resquícios difíceis de serem erradicados. (ROMANI, 2015, p. 200)

Romani defende que as pesquisas acadêmicas, na medida em que insistem na preservação de uma imagem favorável a Vargas - fundamentada nas políticas trabaIhistas de seu governo -, acabam contribuindo para legitimar no senso comum o legado positivo do varguismo ao invés de questioná-lo e desconstruí-lo. Logo, o autor não enxerga como esses estudos, que ocultam a repressão, a violência e a arbitrariedade do Estado Novo, poderiam contribuir para o aprofundamento da democracia no país (ROMANI, 2015, p. 228).

Este primeiro tópico do artigo procurou apresentar o debate historiográfico em torno do Estado Novo a partir das produções iniciadas na década de 80, mostrando que a contestação dos modelos teóricos erigidos em torno do populismo abriu caminho para novas problematizações. Assim, ganharam espaço abordagens que identificavam na classe trabalhadora um sujeito ativo, o que fez com que os vínculos entre camadas populares e Estado/líder fossem revistos e ressignificados. Da mesma forma, em última análise, colocou-se em discussão a representação - ora positiva, calcada na legislação trabalhista, ora negativa, relembrando o autoritarismo do governo - que a historiografia passou a cunhar do regime estadonovista e de Vargas.

Essas representações também se deram por parte dos atores históricos e remontam ao período final do Estado Novo, quando assistimos a um esforço da oposição política em confrontar a imagem positiva que o regime estadonovista procurou difundir para si. Nesse caso, como procuraremos mostrar, tais representações carregavam os 


\section{artigos}

Julia Nogueira Zon

interesses dos grupos e/ou indivíduos que as elaboraram em meio a um contexto específico. Isto posto, no interior do debate historiográfico apresentado, o presente artigo se insere na perspectiva de análise das representações políticas, flertando com o campo de estudo dos imaginários sociais. A novidade consiste no fato de que a abordagem aqui pretendida diz respeito ao período pós-45, isto é, quando a oposição varguista encontrou espaço para delinear sua imagem do ditador deposto, de forma que, em uma perspectiva mais ampla, podemos encarar esse momento como a gênese de uma memória varguista em chave negativa, levando em consideração a fonte escolhida para análise - no caso, a obra Falta Alguém em Nuremberg (1947) do jornalista David Nasser.

\section{Considerações acerca do conceito de representação}

Alinhado com o que foi exposto, faz-se necessário uma breve apresentação do conceito utilizado na análise, isto é, o conceito de representação segundo o historiador Roger Chartier. De acordo com esse autor, "as lutas de representações têm tanta importância como as lutas econômicas para compreender os mecanismos pelos quais um grupo impõe, ou tenta impor, a sua concepção do mundo social, os valores que são os seus, e o seu domínio" (CHARTIER, 1990, p. 17). Chartier aponta que as representações aspiram à universalidade e são determinadas pelos interesses dos grupos que as forjam, o que faz necessário o relacionamento dos discursos proferidos com a posição de quem os utiliza. Assim, as representações não constituem discursos neutros, mas tendem a impor autoridade perante outros, a legitimar um projeto reformador e até a justificar escolhas e posicionamentos. As representações estariam, então, inseridas em um campo de disputa, no qual determinados grupos tentam impor a sua concepção do mundo social (CHARTIER, 1990, p. 17). 


\section{artigos}

\section{Falta alguém em Nuremberg}

Tendo isso em vista, ao trabalhar com o conceito de representação, o presente artigo pretende expor, através da análise do livro Falta Alguém em Nuremberg (1947) de David Nasser, como a imagem negativa de Vargas e do regime estadonovista foi sendo mobilizada e construída para atender aos interesses de um grupo - os liberais agrupados na UDN - que almejava conquistar o poder político no processo de democratização. Contudo, antes de partirmos para a compreensão da fonte propriamente dita, é indispensável apresentar o contexto no qual a UDN emerge e suas principais pautas de defesa.

\section{Os liberais pós-Estado Novo}

Os primeiros anos da década de 1940 foram de intensa mobilização por parte de setores nacionais que exigiam o fim do Estado Novo e a retomada das instituições democráticas. Dentro desse contexto está inserido o "Manifesto dos Mineiros", publicado em 1943. Esse documento foi a primeira manifestação organizada e assinada por membros das elites liberais contra a ditadura e tinha como motivação o desejo desse grupo em retomar o protagonismo da luta pela democratização (BENEVIDES, 1981, p. 34-35). A partir do Manifesto, outras declarações similares começaram a vir a público, intensificando o movimento contrário ao regime de 37.

A fundação da União Democrática Nacional (UDN) em 7 de abril de 1945 foi resultado dessa atividade da oposição. Constituída com o objetivo de acelerar a queda de Vargas, a UDN reuniu diferentes setores da sociedade brasileira. Segundo a historiadora Maria Victoria Benevides, cinco categorias compunham seu elenco no período inicial, a saber: a) as oligarquias destronadas com a Revolução de 30; b) os antigos aliados de Vargas, marginalizados depois dos eventos de 1935 e 1937; c) os que participaram do Estado Novo, mas se afastaram antes de 1945; d) os grupos liberais com forte identificação regional; d) e as esquerdas, como os socialistas da Esquerda Democrática, 


\section{artigos}

Julia Nogueira Zon

os comunistas que não seguiram a diretriz oficial do partido e os estudantes recémegressos da Faculdade de Direito de São Paulo (BENEVIDES, 1981, p. 29-31).

De acordo com a autora, o quadro histórico foi de suma importância para essa conformação política, posto que "[...] somente a conjuntura especial de fins de 1944 e começos de 1945, fruto da galopante desagregação das forças estadonovistas [...] poderia proporcionar a união de elementos tão diversos, quando não antagônicos" (BENEVIDES, 1981, p. 24). Entretanto, essa união não durou muito tempo e, ainda no ano de 1945, alguns grupos que participavam da UDN optaram pelo seu desligamento. No caso dos liberais que compunham o partido, sua reação ao Estado Novo era pautada por propostas de cunho liberal ao mesmo tempo em que guardava resquícios reacionários:

[...] trata-se de voltar à Constituição de 34, resgatar o idealismo dos tenentes (o "saneamento moral da vida política"), os ideais autênticos da Revolução de 30, "traída por Getúlio Vargas". A ambiguidade se revela: progressista, enquanto inimiga do estado fascista; reacionária enquanto seduzida no saudosismo histórico. Em outros termos, a UDN é progressista no que se opõe, reacionária no que propõe. Diante de Getúlio e o Estado Novo - considerados "um desvio" da História - o udenista reage como se fosse possível voltar a 1930 e tudo recomeçar, numa restauração política e... moral. (BENEVIDES, 1981, p. 250, grifo do autor)

Contudo, Benevides chama atenção para o fato de que na UDN "a ética dos fins últimos termina por prevalecer, na crença de que um regime autoritário será transitório e necessário para a realização da democracia" (BENEVIDES, 1981, p. 255, grifo do autor). Tal concepção - aliada ao anticomunismo e à defesa da ordem social - explicaria o fato de alguns setores liberais terem despendido apoio ao governo Vargas.

Oficializada a candidatura udenista do brigadeiro Eduardo Gomes para concorrer à presidência da República nas eleições de 45, a campanha mobilizou setores da classe média, intelectuais e Forças Armadas, mas não chegou a alcançar os trabalhado- 


\title{
artigos
}

\section{Falta alguém em Nuremberg}

res (BENEVIDES, 1981, p. 45). Aproveitando o episódio da marmita, a oposição queremista encabeçou uma intensa campanha contra o brigadeiro, que passou a ser identificado como o candidato dos grã-finos. Por outro lado, a imprensa liberal aderiu em peso ao candidato da UDN:

\begin{abstract}
A campanha do Brigadeiro foi intensamente acompanhada pela imprensa à qual se deve, sem dúvida, a construção de uma imagem altamente positiva e, sobretudo, de um clima otimista em relação à vitória nas eleições. Em São Paulo, o jornal O Estado de S. Paulo, no Rio de Janeiro, o Correio da Manhã, o Diário de Notícias e o Diário Carioca, principalmente, reproduziam os discursos do Brigadeiro pelas cidades; os Diários Associados patrocinaram a campanha no país inteiro. (BENEVIDES, 1981, p. 46)
\end{abstract}

O antigetulismo e a postura acusatória da UDN se acentuaram consideravelmente a partir de 1952, girando em torno de três grandes temas: a desgraça do país com o retorno de Vargas à presidência, a partir da insistência na lembrança do Estado Novo; as denúncias de corrupção administrativa; e a necessidade de uma intervenção militar (BENEVIDES, 1981, p. 84). Dessa forma, mesmo com o fim da ditadura de 37, os udenistas continuaram liderando a oposição a Vargas e aos demais políticos trabalhistas nos anos posteriores a 1945. Como afirma Benevides, "a reação a alguma coisa, a rejeição do getulismo, torna-se a fixação udenista e o corolário de seu liberalismo" (BENEVIDES, 1981, p. 250, grifo do autor).

Entre as características desse liberalismo, vale ressaltar o seu profundo caráter burguês - sem a real participação das camadas populares -, somado à defesa da economia de mercado, da propriedade privada e dos direitos individuais. Todavia, o liberalismo político udenista entra em contradição na medida em que há um apelo recorrente à intervenção militar como alternativa de ação política e a imposição de limites à participação política popular (BENEVIDES, 1981, p. 247-249).

Para tanto, o udenismo atuou em defesa do liberalismo e em oposição aos governos ditos populistas. Em geral, os liberais agrupados nesse partido procuraram, 


\section{artigos}

Julia Nogueira Zon

através de uma representação negativa de Vargas, construir um novo imaginário social que rivalizava com a imagem produzida e difundida, durante os anos do regime, de uma sociedade harmônica e justa e de um chefe de Estado clarividente. Como veremos adiante, esse grupo passou a cunhar um novo quadro de imagens para os anos em que Getúlio esteve no poder: o período passava a ser classificado como uma ditadura atrelada ao fascismo, na qual predominou o cerceamento das liberdades e a tirania. Isto posto, tomando como fonte o livro Falta Alguém em Nuremberg (1947) de Nasser, procuraremos demonstrar como essa representação foi feita e de que forma ela atendia aos interesses dos liberais associados à UDN.

\section{Falta Alguém em Nuremberg}

A obra Falta Alguém em Nuremberg: torturas da polícia de Filinto Strubling Müller foi escrita pelo jornalista David Nasser e publicada em 1947. Nasser foi um dos mais importantes e conhecidos jornalistas brasileiros dos anos 1950 e sua trajetória profissional esteve associada à revista semanal O Cruzeiro, da qual fez parte de 1943 a 1974 (CARVALHO, 2001). Sempre elogiado pela sua habilidade de escrita, era conhecido por produzir reportagens polêmicas, sensacionalistas e sem compromisso com a veracidade das informações. Dono de um posicionamento político profundamente conservador, Nasser foi um ferrenho crítico de Vargas e dos trabalhistas, encabeçando duras denúncias contra o ditador a partir do fim do Estado Novo. Entretanto, anos mais tarde, participaria ativamente do golpe civil-militar de 1964. De acordo com Letícia Nunes de Moraes, o jornalista "apoiou o regime militar em todas as suas etapas, mesmo nos períodos de maior violência repressiva, sempre fazendo coro com o discurso dos presidentes militares" (MORAES, 2011, p. 81).

Dividido em vinte capítulos, o livro foi resultado de uma série de reportagens escritas por Nasser para a revista de Chateaubriand no decorrer dos anos 1946-47, 


\section{artigos}

\section{Falta alguém em Nuremberg}

denunciando os crimes cometidos pelos aparatos policial e institucional varguistas entre os anos 1930-45. A obra Falta Alguém em Nuremberg vem dar continuidade a esse trabalho trazendo um compilado dessas reportagens com outras de caráter inédito. As acusações do jornalista giravam em torno de dois personagens, peças chave no seu livro-reportagem, a saber: Getúlio Vargas e Filinto Müller.

Como o conteúdo do livro é extenso, concederemos destaque a alguns pontos que demonstram o movimento que o autor fez para construir uma imagem negativa de Vargas e de seu governo. Já no prefácio da obra, o jornalista se mostrou bem firme no teor de suas acusações: "as atrocidades praticadas no Brasil pela polícia política do Capitão Filinto Strubling Müller excederam, em alguns pontos, as torturas infligidas pela Gestapo aos judeus, antinazistas e prisioneiros aliados" (NASSER, 1966, p. 5). Segundo o historiador Ernesto Bohoslavsky, a identificação da UDN com os ideais democráticos "[...] foi exercida como uma característica central de suas propostas políticoeleitorais e de sua autoimagem" (BOHOSLAVSKY, 2013, p. 80, tradução nossa). Se por um lado, a oposição construía sua imagem associada à defesa da democracia, por outro, o regime varguista passava a ser identificado com o nazifascismo europeu. Não por acaso, Nasser utilizou a associação entre o Estado Novo e a Alemanha nazista como uma estratégia discursiva em Falta Alguém em Nuremberg.

Apesar de Filinto Müller ganhar destaque na obra em função das diversas acusações de tortura e prisões arbitrárias a ele imputadas durante o período em que ocupou a chefia da polícia do Distrito Federal, Nasser "julga-o, porém, o segundo grande responsável pelos crimes praticados sob sua direta orientação" (NASSER, 1966, p. 6). De acordo com o jornalista, “o primeiro grande culpado, a seu ver, é o Sr. Getúlio Vargas, que poderá fugir a todos os julgamentos atuais, mas não escapará ao implacável, justo e sereno veredicto da História" e "logo que os fatos se coloquem dentro da pers- 


\section{artigos}

Julia Nogueira Zon

pectiva de análise, ele será apontado no Brasil como o maior assassino dentre os assassinos que viveram no tempo de sua vida" (NASSER, 1966, p. 6). Ao reescrever a história dos anos 1930-45, Nasser criou uma representação de Vargas como a personificação do mal. Assim, veremos que a escolha dos fatos que compõem a obra também foi pensada para reforçar essa imagem.

Falta Alguém em Nuremberg apresenta, em uma narrativa de ordem cronológica, os acontecimentos a partir da Revolução de 1930. Nesse âmbito, o autor pontuou que apesar de Vargas ter transmitido no começo do governo certa brandura em relação à oposição política, esse posicionamento não durou muito tempo e logo se iniciaram uma série de prisões arbitrárias no país. De acordo com ele, a partir daí "começava uma era de monstruosidade" (NASSER, 1966, p. 9). Apesar dessa breve introdução, Nasser não se deteve em uma análise profunda acerca das mudanças que a sociedade brasileira passou nesses quinze anos, de forma que os avanços sociais são completamente omitidos e ignorados, uma vez que poderiam colocar em xeque seu objetivo de deslegitimar o varguismo. Para tanto, qualquer menção à legislação trabalhista ou à ligação entre Vargas e as classes trabalhadoras foi completamente ocultada da obra. Segundo Benevides:

Getúlio enfrentou problemas que um liberal moderno não poderia ignorar; a resistência udenista em admitir a participação política das classes populares, a omissão nos debates sobre as questões trabalhistas, será típica do pensamento liberal clássico e elitista, que se refletirá também, no irrealismo político da UDN, ao opor o formalismo legal aos direitos sociais (greves, ampliação da cidadania política), e à modernização da intervenção do Estado. (BENEVIDES, 1981, p. 250)

No decorrer de sua exposição, Nasser privilegiou e enfatizou a face autoritária do regime, sendo esta a principal temática explorada no decorrer das páginas. O tom de denúncia é constante: "O número de presos aumentava dia a dia. Levas e levas tomavam o rumo da Colônia, espécie de campo de concentração da pior espécie" (NASSER, 1966, p. 11). Ainda segundo o jornalista, "exemplos da Itália, da Alemanha e de Portugal pareciam agradar ao detentor do Poder. O Brasil estava às vésperas de uma ditadura" (NASSER, 1966, p. 14). Novamente, a proximidade de Vargas com os regimes 


\title{
artigos
}

\section{Falta alguém em Nuremberg}

nazifascistas da Europa foi utilizada para delinear o caráter do regime brasileiro e o perfil de seu governante.

As denúncias prosseguem com a descrição da Cadeia de Recife, da Colônia Correcional de Dois Rios em Ilha Grande e do presídio na llha de Fernando de Noronha. Mesclando os relatos de presos, Nasser narrou as condições do cárcere, dando destaque para a fome, doenças, superlotação, mutilação, espancamentos e assassinatos que ocorriam dentro das cadeias sob a ordem e conhecimento das chefias prisionais (NASSER, 1966, p. 18-19, p. 37-40, p. 42). As vítimas da barbárie ganhavam nomes e profissões, entre elas estavam trabalhadores, pais de família, esposas e filhas. A descrição minuciosa e apavorante dos métodos de tortura empregados pela polícia foi explorada de forma dramática a fim de comover o público leitor e reiterar o autoritarismo do governo:

\begin{abstract}
Os primeiros detidos sofrem torturas espantosas. Uns resistem heroicamente aos apertos dos testículos, aos maçaricos nas nádegas e na sola dos pés e às duras pancadas nas costas e nos rins. As sessões espíritas funcionam dia e noite sem parar. A "máscara de ouro", a cadeira americana, as unhas arrancadas com alicates, os alfinetes espetados embaixo das unhas, os "adelfís", eis os instrumentos de suplício que arrancam gargalhadas dos policiais. [...] Se o preso surrado, martirizado, ensanguentado, sem unhas, ainda resistia, eles mandavam buscar a esposa ou a filha e, na presença do homem resistente, ela era espancada. Se ele ainda se mantivesse firme, a mulher era posta nua, e em sua vagina os miseráveis introduziam buchas de mostarda. (NASSER, 1966, p. 48-49)
\end{abstract}

O autor buscou relembrar casos específicos cujas vítimas foram figuras de relevo no meio da oposição política. Um deles dizia respeito ao militante comunista internacional Harry Berger e sua esposa, presos em decorrência da derrota do Levante Comunista de 1935. O jornalista d'O Cruzeiro trazia em detalhes as diversas sessões de tortura a que Berger e sua mulher estiveram submetidos. Sobre o desfecho dos dois, Nasser discorreu que enquanto o militante enlouqueceu na prisão em função dos constantes maus tratos, sua esposa teria sido “[...] entregue pelo Sr. Filinto Müller, por ordem do Sr. Epígrafe, São Paulo, v. 10, n. 1, pp.194-217, 2021 


\section{artigos}

Julia Nogueira Zon

Getúlio Vargas, ao Sr. Adolf Hitler e executada num dos campos de concentração da Alemanha." (NASSER, 1966, p. 69, grifo nosso).

Outro caso abordado foi o de Olga Benário, esposa do revolucionário brasileiro Luís Carlos Prestes. Ao narrar o episódio da prisão de Olga e Prestes, Nasser expôs que a intenção da polícia era matar o líder comunista no momento da detenção, sendo que "tais ordens, certamente, vinham de mais alto. Emanavam de um poder superior. Ordens do próprio Sr. Getúlio Vargas" (NASSER, 1966, p. 70, grifo nosso). O jornalista discorreu sobre os últimos momentos de Olga na Casa de Detenção, de onde, mesmo grávida, fora deportada para a Alemanha nazista:

Um pedido de adiamento da remoção para quando ela estivesse em melhor estado é recusado pela Polícia. A ordem viera de muito alto. Não era possível o chefe ir à presença do Sr. Getúlio Vargas e dizer, simplesmente: - "Escuta aqui, chefão, a mulher está ruim. Fica para depois a remoção". Nada disso. Olga Prestes era um presente de Getúlio para Hitler. (NASSER, 1966, p. 72, grifo nosso)

Como foi mostrado nesta exposição da obra, as atrocidades imputadas à Filinto Müller e a polícia política no geral foram utilizadas para reafirmar a imagem de um Vargas tirano. Mesmo não havendo comprovação sobre a veracidade de algumas das informações apresentadas no decorrer do livro, o jornalista fez questão de destacar que as ordens para a execução de torturas, assassinatos e deportações sempre emanaram da maior autoridade do país: Getúlio Vargas. Desse modo, Nasser reescreveu a história dos anos 1930-45 privilegiando uma narrativa que, ao invés de relembrar as conquistas trabalhistas, colocou em evidência um período marcado pela violência. Assim, o autor construiu sobre a base ideológica liberal uma nova imagem de Vargas e do 


\section{artigos}

\section{Falta alguém em Nuremberg}

seu regime fundamentada no autoritarismo. Essa nova representação entrou em embate com a imagem erigida, durante os anos do Estado Novo, de um governo justo e de um chefe de Estado clarividente.

É importante relembrar que Nasser estava ligado a uma revista pertencente aos Diários Associados de Chateaubriand, de maneira que suas reportagens também correspondiam aos interesses desse grupo. Como bem recorda Capelato, o dono dos Diários, apesar de defender os ideais liberais antes do golpe de 37, não se intimidou em aderir ao regime autoritário:

Assis Chateaubriand não se preocupou em distinguir o Estado Novo dos Estados totalitários. Defendeu o modelo nazista sem nenhum constrangimento. O ideário liberal orientou a atuação de seus periódicos até o Golpe. Mas imediatamente após a instauração do novo regime, o periodista externou total apoio a ele e solicitou do Chefe que dirigisse o país inspirado em Hitler. (CAPELATO, 1989, p. 222)

O próprio Nasser, nos anos da ditadura, "elogiou Vargas, seus ministros, suas obras, e nem com lupa se encontra qualquer matéria crítica ou pelo menos imparcial em relação ao Estado Novo" (CARVALHO, 2001, p. 146). Contudo, com a crise do regime estadonovista "os liberais, pouco a pouco, recuperaram a voz; os cooptados não tardaram em retirar o apoio ao regime; e a fala apologética foi substituída pelo discurso de oposição engavetado em 1937" (CAPELATO, 1989, p. 233). Assim, vemos como a representação que o jornalista construiu de Vargas como tirano - ao invés de benfeitor - em Falta Alguém em Nuremberg, carregava os interesses de um grupo político do qual ele fazia parte - uma vez que membro dos Diários - e como esses interesses respondiam às demandas de um outro contexto histórico, o da redemocratização. Ainda de acordo com Capelato:

A imprensa liberal se norteou pelos princípios do liberalismo político, embora seus representantes tenham feito concessões quando julgaram necessário. Mas para defender os próprios interesses e os da classe a que pertenciam, aceitaram medidas repressoras e antiliberais nos momentos em que sentiram ameaçada a ordem social: nessa situação apoiaram o "tirano" e depois foram vítimas dele.

Epígrafe, São Paulo, v. 10, n. 1, pp.194-217, 2021 


\section{artigos}

Julia Nogueira Zon

Porque os proprietários de jornal, na salvaguarda de seus interesses e manutenção dos privilégios de classe, preferiam ser vítimas da "tirania do poder" do que da "tirania das massas". O "tirano" recusa-lhes a liberdade, só que protege seus bens. Os representantes do OESP [O Estado de S. Paulo], por exemplo, foram perseguidos pela ditadura, mas em 1945 recuperaram uma empresa próspera e retornaram (após anos de exílio) para uma sociedade cujos conflitos haviam sido momentaneamente controlados. Para os liberais brasileiros, a principal tarefa do poder político é impedir que as massas se rebelem, pondo em risco a propriedade. Diante dos perigos da "patuléia exaltada" (a expressão é do OESP), as concessões são consideradas legítimas. Em tal postura não há ambiguidade, pois esse é o limite da democracia liberal. (CAPELATO, 1989, p. 246)

Para tanto, as representações de Vargas dialogavam com os novos interesses que se manifestavam pelos sujeitos e grupos políticos. Com a democratização, a disputa partidária não podia ignorar a ligação entre Vargas e as classes trabalhadoras fato que ficará demonstrado com o movimento queremista e com a influência de Vargas sobre o resultado da eleição presidencial em 1945. Como afirma Ângela Gomes:

[...] a definitiva entrada do trabalhador no cenário político, destruindo todos os cálculos tradicionalmente cultivados no país, ligava-se à entrada em cena de dois novos partidos: o PC e o PTB. Tanto a UDN quanto o PSD testemunhavam a insuficiência dos apelos que não se dirigiam maciçamente ao povo. Os partidos do futuro teriam que contar com este ator fundamental. (GOMES, 1994, p. 276)

Era imprescindível que, como grupo político, os liberais agrupados na UDN procurassem reverter a imagem de Getúlio como líder das massas trabalhadoras a fim de obterem espaço na cena política brasileira. Nesse sentido, a disputa político-eleitoral se transpôs também para o campo das representações, na qual pudemos observar a construção de uma imagem negativa do regime estadonovista e de seu chefe. 


\section{artigos}

\section{Falta alguém em Nuremberg}

\section{Considerações finais}

O presente artigo, através da análise da obra Falta Alguém em Nuremberg de David Nasser, procurou apresentar como os liberais agrupados na UDN passaram a representar Getúlio Vargas e o Estado Novo após 1945. Nas mãos do jornalista da revista O Cruzeiro, Vargas passou a ser identificado como a encarnação do mal, assumindo a postura de um governante autoritário. Fascista, tirano, ditador e assassino foram alguns dos adjetivos utilizados para qualificá-lo. Em conjunto, esse novo quadro de imagens procurava atribuir a Vargas a responsabilidade direta por todos os crimes cometidos durante o período em que esteve à frente do poder. Curiosamente, Nasser criticou no varguismo as mesmas práticas das quais ele foi conivente no regime militar de 1964.

De fato, não se nega que o regime varguista foi autoritário ou que muitos de seus apoiadores fossem simpáticos à doutrina nazifascista. Todavia, chamamos atenção para a forma como Nasser explorou essa temática através da construção de uma narrativa maniqueísta e repleta de sensacionalismos. A violência do regime foi ampliada ao máximo, de forma que não há espaço para uma análise histórica, política ou sociológica - e talvez esse nem fosse o objetivo da obra. Em confluência com os interesses do próprio autor e do grupo no qual ele estava inserido enquanto membro dos Diários, Falta Alguém em Nuremberg procurava difundir uma outra representação de Vargas pautada nas demandas de um novo contexto histórico.

Como vimos, a presença dos trabalhadores transformou a dinâmica política no pós-45. Na medida em que seus votos passaram a influir nos resultados eleitorais, eles se converteram em objeto de disputa entre os partidos políticos. Paralelo a isso, Vargas demonstrava acumular grande influência sobre o cenário político brasileiro, sua imagem como "pai dos pobres" ainda estava presente no imaginário popular, alcançando, 


\section{artigos}

Julia Nogueira Zon

sobretudo, as classes trabalhadoras. Para os setores liberais reunidos na UDN, o prestígio de Vargas se colocava como um obstáculo, uma vez que dificultava os ganhos desse setor no jogo político. Nesse sentido, a construção de uma representação negativa de Vargas e do seu regime correspondia aos anseios de um grupo político que, no contexto do processo de redemocratização e reorganização das instituições, procurava ganhar espaço na cena pública. Tal conquista do poder político passava pela desconstrução da imagem de Vargas como "pai dos pobres" e criação de um novo imaginário social em que ele figurasse como inimigo da democracia.

\section{Referências bibliográficas}

NASSER, David. Falta Alguém em Nuremberg: torturas da polícia de Filinto Strubling Müller. 4 ed. Rio de Janeiro: O Cruzeiro, 1966.

BENEVIDES, Maria Victoria de Mesquita. A UDN e o udenismo: ambiguidades do liberalismo brasileiro (1945-1965). Rio de Janeiro: Paz e Terra, 1981.

BOHOSLAVSKY, Ernesto. Antiperonismo y Antivarguismo (1943-1955): similitudes, diferencias y vínculos. Anuario de la Escuela de Historia, n. 24, p. 73-97, 23 feb. 2013.

CANCELLI, Elizabeth. 0 mundo da violência: a polícia da Era Vargas. 2 ed. Brasília: UnB, 1994.

CAPELATO, Maria Helena Rolim. Multidões em cena: propaganda política no varguismo e no peronismo. 2.ed. São Paulo: UNESP, 2009.

Os arautos do liberalismo: a imprensa paulista (1920-1945). São Paulo: Brasiliense, 1989.

M. H. R.; DUTRA, E. R. de F. . Representação Política: O Reconhecimento de um Conceito na Historiografia Brasileira. In: CARDOSO, C. F. ; MALERBA, J. (Org.). Representações: contribuição a um debate transdisciplinar. Campinas: Papirus, 2000, p. 227267.

CARVALHO, Luiz Maklouf. Cobras Criadas: David Nasser e O cruzeiro. 2 ed. São Paulo: SENAC, 2001. 


\section{artigos}

Falta alguém em Nuremberg

CHARTIER, Roger. A história cultural: entre práticas e representações. Tradução de Maria Manuela Galhardo. Lisboa: DIFEL; Rio de Janeiro: Bertrand Brasil, 1990.

FERREIRA, Jorge. O imaginário trabalhista: getulismo, PTB e cultura política popular 1945-1964. Rio de Janeiro: Civilização Brasileira, 2005.

(Org.). $\mathbf{O}$ populismo e sua história: debate e crítica. Rio de Janeiro: Civilização Brasileira, 2001.

; DELGADO, Lucilia de Almeida Neves (Org.). O Brasil republicano, vol. 3. O tempo da experiência democrática: da democratização de 1945 ao golpe civil-militar de 1964. Rio de Janeiro: Civilização Brasileira, 2003, p. 13-46.

GOMES, Ângela de Castro. A invenção do trabalhismo. 2.ed. Rio de Janeiro: Relume Dumará, 1994.

MORAES, Letícia Nunes de. As bandeiras de David Nasser. Trama Interdisciplinar, v. 2, n. 1, p. 74-88, 2011.

ROMANI, Carlo. A ditadura tolerada: herança autoritária na historiografia sobre Vargas. In: Ditaduras: a desmesura do poder. AVELINO, Nildo; TELMA, Dias; MONTOIA, Ana (Org.). São Paulo: Intermeios; Brasília: Capes, 2015, p. 197-230.

SANTOS, Rodolpho Gauthier Cardoso dos. Antiperonismo e antivarguismo: as reportagens fotográficas de David Nasser sobre a Argentina (1946-1955). In: Encontro Internacional da Anphlac, 11., 2014, Niterói. Anais eletrônicos do XI Encontro Internacional da Anphlac, 2014. 